DOI https://doi.org/10.30525/978-9934-26-006-3-2

\title{
РАРИТЕТНІ ВОДНІ УГРУПОВАННЯ НАЦІОНАЛЬНОГО ПРИРОДНОГО ПАРКУ «НИЖНЬОДНІПРОВСЬКИЙ» (ХЕРСОНСЬКА ОБЛ., УКРАЇНА)
}

\author{
Дзеркаль В. М. \\ заступник начальника науково-дослідного відділу \\ Начіональний природний парк «Нижньодніпровський» \\ м. Херсон, Україна \\ Давидова А. О.
}

молодший науковий співробітник відділу геоботаніки та екології

Інституту ботаніки імені М. Г. Холодного

Національної академії наук України

м. Київ, Україна

\section{Пономарьова А. А.}

заступник директора з науково-дослідної роботи - начальник відділу

Наиіональний природний парк «Нижньодніпровський»

м. Херсон, Україна

Території від Каховської ГЕС до Дніпро-Бузького лиману, як одного 3 найцінніших природних заплавно-літоральних комплексів у Європі, Указом Президента України від 24 листопада 2015 року № 657/2015 «Про створення національного природного парку «Нижньодніпровський» надано природоохоронний статус - національний природний парк «Нижньодніпровський».

Одним із важливих показників цінності об'єкту природнозаповідного фонду $€$ наявність угруповань, уключених до «Зеленої книги України». Вона є основою для розроблення охоронних заходів щодо збереження, відтворення та використання занесених до неї природних рослинних угруповань. Охорона цих угруповань спрямовується на збереження їх ценотичної структури, популяцій рідкісних видів рослин та умов місцезростання.

У виданні «Зеленої книги України» 2009 року для пониззя річки Дніпро вказано 15 формацій: альдрованди пухирчастої (Aldrovandeta vesiculosae), водяного жовтецю Ріона (Batrachieta rionii), куги приморської (Schoenoplecteta littoralis), куширу донського (Ceratophylleta tanaitici), куширу напівзануреного (Ceratophylleta 
submersi), лепешняку тростинового (Glycerieta arundinaceae), плавуна щитолистого (Nymphoideta peltatae), пухирника малого (Utricularieta minoris), рдесника сарматського (Potamogetoneta sarmatici), ряски горбатої (Lemneta gibbae), стрілолисту стрілолистого (Sagittarieta sagittifoliae), сальвінії плаваючої (Salvinieta natantis), водяного горіху плаваючого (Trapeta natantis), латаття білого (Nymphaeeta albae) та глечиків жовтих (Nuphareta luteae) [1, с. 294-346]. Оскільки сучасні межі НПП «Нижньодніпровський» охоплюють майже усю гирлову частину Дніпра, приймаємо ці вказівки для і території національного природного парку. У Літописі природи за матеріалами проєкту організації наведено 14 формацій [2, с. 256-257].

За результатами геоботанічних досліджень 2019-2020 pp. на окремих ділянках НПП «Нижньодніпровський» було зафіксовано три формації: Salvinieta natantis, Trapeta natantis та Nuphareta luteae. Угруповання типової формації Salvinieta natantis представлені наступними асоціаціями - зануренокуширово-плаваючосальвінієва (Salvinietum (natantis) ceratophyllosum (demersi), малорясковоплаваючосальвінієва (Salvinietum (natantis) lemnosum (minoris)), плаваючосальвінієва чиста (Salvinietum natantis purum). Угруповання типової формації Trapeta natantis представлені такими асоціаціями водяногоріховою чистою (Trapetum natantis purum), зануренокуширово-водяногоріховою (Trapetum (natantis) ceratophyllosum (demersi)), плаваючосальвінієво-водяногоріховою (Trapetum (natantis) salviniosum (natantis)). Угруповання типової формації Nuphareta luteae представлені водяногоріховожовтоглечиковою (Nupharetum (luteae) traposum (natantis)) та плаваючосальвінієво-жовтоглечиковою salviniosum (natantis)) асоціаціями.

Незначну кількість віднайдених угруповань, уключених до «Зеленої книги України», можна пояснити декількома причинами: по-перше, НПП «Нижньодніпровський» відносно недавно створений, тому інвентаризація флори та рослинності досі продовжується; по-друге, після зарегулювання 1956 року у пониззі Дніпра, частина угруповань вірогідно деградувала або навіть зникла. Також дуже розповсюдженим $\epsilon$ помилково спрощений підхід до розуміння формацій - так, за наявності угруповань, сформованих виключно назвоутворюючим видом (але у багатьох випадках асоціації не є монодомінантними), фіксується факт трапляння формації на певній території. Особливо цей підхід є притаманним саме для об'єктів природно-заповідного фонду, що пояснюється небажанням переглядати перелік формацій ЗКУ через 
загрози зниження цінності території та складність пояснень державним структурам причин зменшення кількості формацій від часу створення об’єкту ПЗФ. Наприклад, для НПП «Нижньодніпровський» наводиться формація латаття білого (Nymphaeeta albae) [2, 256-257], але жодної асоціації, які уключено до «Зеленої книги України», авторами виявлено не було. Втім, відмічено широко розповсюджені з високим ступенем концентрації ценози Nymphaeetum albae purum та Nymphaeetum (albae) ceratophyllosum (demersi). Припускаємо, що флористичний склад угруповань збіднів, тому навіть якщо з часом буде підтверджено знахідки таких асоціацій, як Nymphaeetum (albae) traposum (natantis) або Nymphaeetum (albae) salviniosum (natantis) на території НПП, вони будуть малочисельними. Тому пропонуємо охороняти додатково на регіональному рівні наступні асоціації: жовтоглечикову чисту (Nupharetum (luteae) purum), жовтоглечиково-зануренокуширову (Nupharetum (luteae) ceratophyllosum (demersi)), білолататтєву чисту (Nymphaeetum albae purum), білолататтєво-зануренокуширову (Nymphaeetum (albae) ceratophyllosum (demersi)).

За методикою синфітосозологічної оцінки рослинних угруповань [1, с. 12-16], було проаналізовано 12 асоціацій раритетного фітоценофонду національного природного парку «Нижньодніпровський» (таблиця 1). 3 огляду на той факт, що ознаки розглядалися для території НПП, автори не враховували ознаку «регіональна репрезентативність», яка характеризує представленість раритетних угруповань у системі одиниць геоботанічного районування [2, с. 12].

До другого синфітосозологічного класу, який репрезентує регіонально рідкісні, вразливі угруповання, належить вісім синтаксонів, два 3 яких ми пропонуємо як нові. Третьому класу відповідають типові зональні угруповання, досить широко розповсюджені і стійкі до антропогенних факторів, вони на території НПП представлені чотирма асоціаціями.

Отже, на території Національного природного парку «Нижньодніпровський» протягом двох польових сезонів зафіксовано три формації, які уключено до «Зеленої книги України». Вони представлені вісьмома асоціаціями. Також, для охорони на регіональному рівні запропоновано чотири асоціації. Актуальним $є$ продовження інвентаризації раритетних угруповань на території НПП 3 метою виявлення нових локалітетів та підтвердження формацій. 
Таблиця 1

\section{Характеристика раритетних асоціацій НПП «Нижньодніпровський», виділених за принципами домінантної класифікації}

\begin{tabular}{|c|c|c|c|c|c|}
\hline № & Синтаксони & СФІф & $\begin{array}{l}\text { Сума } \\
\text { балів }\end{array}$ & СФІа & СФК \\
\hline 1 & $\begin{array}{c}\text { Salvinietum (natantis) } \\
\text { ceratophyllosum (demersi) }\end{array}$ & $8.0-12.0$ & 60 & 8.5 & II \\
\hline 2 & $\begin{array}{c}\text { Salvinietum (natantis) lemnosum } \\
\text { (minoris) }\end{array}$ & $8.0-12.0$ & 60 & 8.5 & II \\
\hline 3 & Salvinietum natantis purum & $8.0-12.0$ & 63 & 9 & II \\
\hline 4 & $\begin{array}{c}\text { Trapetum (natantis) } \\
\text { ceratophyllosum (demersi) }\end{array}$ & $11.1-14.5$ & 77 & 11 & II \\
\hline 5 & $\begin{array}{c}\text { Trapetum (natantis) salviniosum } \\
\text { (natantis) }\end{array}$ & $11.1-14.5$ & 93 & 13.3 & III \\
\hline 6 & Trapetum natantis purum & $11.1-14.5$ & 93 & 13.3 & III \\
\hline 7 & $\begin{array}{l}\text { Nupharetum (luteae) traposum } \\
\text { (natantis) }\end{array}$ & $11.8-12.2$ & 65 & 9.3 & II \\
\hline 8 & $\begin{array}{c}\text { Nupharetum (luteae) salviniosum } \\
\text { (natantis) }\end{array}$ & $11.8-12.2$ & 59 & 8.4 & II \\
\hline 9 & Nupharetum (luteae) purum & $11.8-12.2$ & 58 & 8.2 & II \\
\hline 10 & $\begin{array}{c}\text { Nupharetum (luteae) } \\
\text { ceratophyllosum (demersi) }\end{array}$ & $11.8-12.2$ & 50 & 6.4 & III \\
\hline 11 & Nymphaeetum albae purum & $10.5-12.2$ & 58 & 8.2 & II \\
\hline 12 & $\begin{array}{l}\text { Nymphaeetum (albae) } \\
\text { ceratophyllosum (demersi) }\end{array}$ & $10.5-12.2$ & 50 & 6.4 & III \\
\hline
\end{tabular}

Умовні позначення: СФІф - синфітосозологічний індекс формацій; сума балів - результат складання вартості ознак; СФІа - синфітосозологічний індекс асоиіацій; СФК (синфітосозологічний клас): $I I-C Ф I=8-11$; III-CФI = 5-8.

\section{Література:}

1. Зелена книга України /під загальною редакцією членакореспондента НАН України Я.П. Дідуха - К.: Альтерпрес, 2009. 448 с. +48 кольор. с.

2. Літопис природи НПП «Нижньодніпровський». Т. 3.- Херсон, 2020. - C. 256-257. 